(1)

George Fox

UNIVERSITY
Digital Commons @ George Fox University

2016

Climatologists, Theologians, and Prophets: Toward an

Ecotheology of Critical Hope

Cherice Bock

Follow this and additional works at: https://digitalcommons.georgefox.edu/gfes

Part of the Christianity Commons 


\section{CLIMATOLOGISTS, THEOLOGIANS, AND PROPHETS: TOWARD AN ECOTHEOLOGY OF CRITICAL HOPE}

\section{Cherice Bock}

s people of faith begin to recognize in larger numbers that our relationship with creation is one of the most important challenges facing us today, I find myself pondering what we have to offer the environmental movement. The Christian scriptures begin and end with stories of God and creation: the oft-mentioned creation stories of Genesis 1-2, and the eschatological reflections on the new heaven and earth, and the river and tree of life in Revelation 21-22. ${ }^{1}$ In between are the stories of the people of faith, and how we interact with God in the midst of creation. These stories place us in the larger picture and give us metaphorical concepts of where we come from, where we are going, and who we are in relation to all that is created. Within this transcendent story, each of us comes from a particular context, a place and time, an individual journey of relational connection to God and to others attempting to follow God's way. In this time and context, our stories are necessarily bound up with the ways that we treat one another and the rest of the natural world, but hope and purpose often feel elusive in religious and nonreligious settings alike.

I am a Christian and a Quaker, with training in the social sciences, theology, and environmental studies and working in the religious academy. As such, I often ask myself what theologians and others involved in the interpretation and praxis of the Christian faith can contribute to caring for the environment in a more holistic way. My particular 
denominational history includes the connection of spiritual contemplation with social justice activism: a prophetic role in the midst of difficult situations. The biblical prophets held together both critique of their present time and hope for the larger meaning and purposes of God, and I wonder if this is the path for ecotheologians in the twenty-first century. Tying all of these strands together, the idea of an ecotheology of critical hope formed in my mind. I suspect that ecotheologians must not simply critique, but we must be willing to enact hope in the midst of the despair that has paralyzed so many regarding issues of environmental import. This paper will show how I got to the idea of an ecotheology of critical hope, and what a lived ecotheology of critical hope could look like.

\section{Theologians as interpreters, not prophets?}

People of faith throughout history have often played the role of prophet, calling their cultures to more ethical treatment of one another, but it is not people of faith who are most often leading the prophetic call in the instance of climate change. In fact, there is a striking similarity between the prophetic and apocalyptic language in the Bible and the rhetoric of climatologists, economists, and even politicians. ${ }^{2}$ Therefore, when I read Forrest Clingerman's article in the Journal of the American Academy of Religion last summer, "Theologians as Interpreters - Not Prophets - in a Changing Climate," I found much that resonated with me, including his jibe at theologians: We are "a pretty helpless bunch" when it comes to fixing environmental problems. ${ }^{3}$ We are not the ones with the technical knowledge to solve the engineering problems that are happening as a result of climate change, or the ones who can create scientific models to help us anticipate the coming changes, or the ones to formulate holistic mitigation plans. We are good thinkers and we can be helpful advocates, and perhaps we can help shift our constituents' worldviews, but we are not the ones who can solve the climate change problems we face as a global community if all we are doing is theological theorizing.

Clingerman suggests that the role of theologians in the climate change conversation is to be mediators and interpreters of climate change, and in many ways, this makes good sense. Given the generally accepted definition of theology as "faith seeking understanding," to seek to understand the issues of ultimacy surrounding climate change and interpret these issues in light of faith traditions and in language 
understandable to the general public is an important role. ${ }^{4}$ It is important for theologians to help sort out the "social frames of meaning" our cultures give to the climate debate. ${ }^{5}$ This may well be the role of the theologian in issues of climate change, I thought to myself.

And yet, something felt like it was missing. If Clingerman is right, and "the theologian is not a lone prophetic voice crying against the dangers of climate change," but instead "the theologian is... a researcher in the midst of a dialogue, reflecting on an interdisciplinary enterprise through its particular methods and outlooks," who are the actors in this system? It is not the climatologists, who Clingerman shows to be prophets of doom but without the agency to move us away from the dreaded apocalyptic outcome. If this is so, who actually carries out the changes required to heal our planet from environmental degradation? To quote Karl Marx's critique, "The philosophers" (and, we might add, the theologians) "have only interpreted the world in various ways; the point, however, is to change it." ${ }^{6}$ Who will change the world if climatologists and theologians are simply presenting and interpreting data?

\section{Role of the ecotheologian: a hermeneutic of prophetic hope}

What I realized was missing was a full account of the prophetic role. In the Judeo-Christian tradition, the prophet is not only an apocalyptic doomsayer, but also a hope-giver. ${ }^{7}$ Though the traditional theologian of the last several centuries, like the traditional scientist, has felt the need to be "objective," stating theory and expecting others to live it out, the issue of climate change has brought many in both fields out into the civic realm with passionate and alarmist cries of warning. ${ }^{8}$ These cries, however, have more often than not engendered fear and inertia in the attitudes of the public, or communicated a sense of inevitability of the apocalyptic conclusion.

It is hope, however, which gives people courage to act faithfully, even in the face of oppression and suffering. The biblical prophet encourages the community of faith to move forward into a hoped-for future world by enabling them to make meaning of the situation. He or she does this by engaging people's imaginations so they can zoom out from present existence to a bigger picture that transcends their suffering, as we do when we invoke the inclusion of the creation motif at the beginning and end of the Christian Bible mentioned at the beginning of this paper. ${ }^{9}$ 
Clingerman moves in the direction of this conversation when he states, "theological reflection is well equipped to uncover narratives that advance our critical powers and offer us hope." He identifies the importance of the location "between hope and fear," which I see as the location of the biblical prophet. ${ }^{10}$ It is curious that the role of theologian as we think of it is not really present in the Christian Bible. ${ }^{11}$ There are priests to keep the rituals going, there are scribes to write and re-write the sacred texts, and there are prophets to help the community imagine itself into its present and future context. In the modern American church, are theologians simply the scribes, recording and reiterating long ago histories of God's interaction with creation? In my view, the role of theologian is the same as the role of the biblical prophet: interpreting in light of current events, leading with one's life and actions, and holding together hope and fear, critique and meaning-making.

Based on Jürgen Moltmann's idea that hermeneutic is not "a simple matter of understanding but is itself performative, an action which is directed toward the transformation of the world," ${ }^{12}$ I posit that if the role of the theologian within the context of climate change is in fact interpretation, it is this expanded version of interpretation: a hermeneutic of transformative practice. It is an interpretation that, through critiquing the world as it is and invoking a vision for the world as it can be, transforms our everyday choices into struggles that have meaning. This critical hope grounds the community in a broader view of history, allowing it to move forward in hope, acknowledging fear but not becoming paralyzed by it.

To be transformative, a critique must, however, be embodied: enacted. It speaks against the current system and has the audacity to not just envision but to also move toward liberation of the entire community of creation. If one accepts this version of the theologian's expanded hermeneutical role, then the theologian becomes indistinguishable from the prophet, expounding and enacting critical hope and, in our particular context, an important focus is ecotheology.

\section{Why critical hope?}

The term "critical hope" is based on Paulo Freire's Pedagogy of Hope, in which he updates his famous Pedagogy of the Oppressed with a more specific focus on hope. ${ }^{13}$ Critical hope is defined as "an action-oriented 
response to contemporary despair" ${ }^{14}$ and is discussed in extant literature in the fields of higher education classrooms, ${ }^{15}$ psychological settings, ${ }^{16}$ and participatory action research in community organizations, ${ }^{17}$ but this concept has thus far not been explored in depth in the theological or environmental literature. ${ }^{18}$

While I do not plan to expound a full ecotheology of critical hope here, what I hope is to show the need for theologians and climatologists to move from a space of critical alienation to one of critical hope, and for many pastors and people of faith to move from a space of uncritical hopefulness into critical hope. To do this, I will first describe what hope is and does, and how the meaning-making process of actively hoping alongside suffering and struggle can serve as a catalyst in the agential process of moving toward a hoped-for world. Then I will explain four categories of individuals within the framework of critical/uncritical and hopeful/alienated. Finally, I will show how, through an ecotheology of critical hope, theologians can participate in a continual, communal, interpretive dialectic between hope and suffering, facing fear by making meaning together through shared experience and stories of struggle and promise.

\section{Critical hope}

Based on Paulo Freire's liberation pedagogy, critical hope is an area pedagogy scholars and practitioners are defining in order to give hope to those working to break the cycle of oppression pinpointed by Freire. ${ }^{19}$ His liberation pedagogy explains the struggle between oppressor and oppressed, the fact that we all are bound up in this struggle and dehumanized by it, and that most of us play both roles at different points in our lives and relationships. To break this cycle requires risking acts of love, seeing one another as human beings, and becoming conscious of the parts played by ourselves and others in this system of oppression, a process he calls "conscientization." ${ }^{20}$ Since Freire "avoided separating pedagogy from theology or philosophy," his work has influenced or can be read alongside a variety of disciplines, including theology, and arguably is in itself a kind of contextual theology for educators, or at least a "pedagogical spirituality." ${ }^{21}$

For theologians, many of whom are also educators, Freire's liberation pedagogy provides helpful and convicting food for thought regarding the 
process of theological education. The system of domination that the church and theological educators often help to perpetuate is expressed in what Freire calls the "banking model of education," where an expert bestows information on students (or parishioners), a transaction rather than a process where critical consciousness occurs. Though this domination system is in direct opposition to the freedom and liberation offered by God in the biblical witness, its oppressive structures infiltrate our church polity and relationships so that the church is always in need of renewal.

For ecotheologians, Freire's framework is doubly helpful, since the anthropogenic problems facing our planet are present because of the fear-based system of domination and control Freire describes. Just as portions of humanity have enforced hierarchies of domination and control on one another in the form of class, race, gender, and nationality, we have also attempted to dominate and control the natural world. The social struggle Freire defined has the same roots as the ecological crisis.

Therefore, for those of us situated within theological education, getting at the root of the problems in both education and our actions toward the environment requires a critical look at our own complicity in the sociopolitical structures of our time. But, as I have shown above, critiquing is not enough, because critique alone leaves us feeling stuck and despairing, without a sense of agency to be able to solve the problems, leading to a pervasive hopelessness and meaninglessness. As Freire puts it:

Hope is an ontological need. Hopelessness is but hope that has lost its bearings, and become a distortion of that ontological need. When it becomes a program, hopelessness paralyzes us, immobilizes us. We succumb to fatalism, and then it becomes impossible to muster the strength we absolutely need for a fierce struggle that will re-create the world. I am hopeful, not out of mere stubbornness, but out of an existential, concrete imperative. ${ }^{22}$

In other words, theology or climatology that stays within the walls of an academy based on the banking model becomes immobilizing and fatalistic. Critical hope provides an alternative: a "tension between fatalism and utopianism... |that] is partially resolved in action." ${ }^{23}$ In order for 
the information on climate change to meet our own and our world's needs, it must be enacted, and the name for this action is critical hope.

\section{Hope as a process}

It is important to further explore the meaning of the word "hope." Often confused with the more passive experiences of wishing, desiring, or optimism, hope refers to something deeper: a choice, a practice, an orientation toward the future while grounded in stories from one's personal and communal past, giving meanings to actions in the present that impact the future. Though one may feel various levels of hopefulness depending on the day, hope itself is not an emotion. It is a process of facing one's fears with courage and within a network of social support and meaningmaking. Hope is both the object hoped for and the feeling one gets as one works to get there. ${ }^{24}$ We can only hope for things that are possible. Otherwise we are either wishing (if the outcome is impossible) or we are certain (if the outcome is inevitable). ${ }^{25}$

Psychological research over recent decades provides a helpful framework for understanding hope. According to hope theorist C. R. Snyder, hope is based on our belief in our ability to reach a goal. We base our understanding of our ability on our past history, perception of our own skill level (self-efficacy), and the amount of motivation or agency we think we have. We decide how much value we place on that goal, and whether or not we see a pathway that could get us there. So the important pieces are: setting a realistic goal, our perceptions of our history, imagining pathways, and believing ourselves to have agency. Hope, in Snyder's view, is the cognitive process of moving through these actions toward one's goal. $^{26}$

Also important, finds Snyder, is one's response to failure, which can come in the form of an obstacle or a feeling of loss of hope. He and other psychologists distinguish between hope and optimism in the way one deals with failure or mistakes. Optimists tend to distance themselves from failure so it does not negatively impact their identity. Those who hope are willing to admit mistakes and failures, and incorporate these into their identity as opportunities for learning and growth. They see these as minor pitfalls on the way to a larger goal. ${ }^{27}$

Though this psychological framework is helpful, one still wonders: What can motivate us to make that step of courage and vulnerability? 
Excepting the most talented and successful individuals, most of us would probably find our agential reserves tapped fairly quickly if our own past and future were all that was involved in the process of hope, and indeed, this seems to be what has happened to many working on issues surrounding climate change. This form of hope, limited to our own lifetimes and achievements, is inadequate to the task of sustained mobilization and transformation that is required to combat climate change. Even in the case of those exceptionally talented and successful individuals just mentioned, we probably all recognize the sense of disappointment and dissatisfaction individuals sometimes feel upon achieving a personal goal such as a job promotion or an acquisition of a particular possession. The goal may have been achieved, but this is not equal to a sense of hope. Missing is the interpretation of the goal completion as having meaning.

What is needed is a hope that is deeper than desire, broader than the individual, and that contains the transformative power to change suffering, injustice, evil, and apathy into meaning. This is the interpretive role that theologians can play, if we are willing to fuse hope and fear, and even suffering, into the courage to live out both sides of the prophetic role of active hope.

\section{Grounding in faith tradition}

In the biblical books, especially those of prophecy and wisdom, one finds two major types of hope: (1) the relatively easy hope of Proverbs, which is the hope for living faithfully within one's own lifetime and providing a safe and livable future for one's children, and (2) a long-term hope of participating in the community of promise. While the former requires some sacrifice, including living righteously rather than receiving all the comforts one sees others receiving, the latter kind of hope requires a much broader story in which to make sense of one's life. If one lived during the time of the Israelites' exile from the Promised Land, for example, one would endure exile with the knowledge of a deeper meaning, with the hope of God's promise of faithfulness to the community. If one lives, as we do, in the time after Jesus, one can hope in the story of suffering, redemption, and liberation God enacted through him, and participate in that story, making meaning of one's life through the lens of that past, present, and future hope. 
Communities of faith have a deep resource of hope in our shared stories, and the infusion of meaning that comes with passing these stories from generation to generation. Not only do we have our own personal stories on which to base our hope, but we also have a vast repository of stories of ancestors and spiritual forebears.

\section{Meaning}

Holding the tension between acknowledging what is wrong in the world and continuing to hope is what Moltmann called the "dialectic of reconciliation," similar to the dialectic of "conscientization" delineated by Freire. ${ }^{28}$ Arguably, it is our ability to hope that makes us human, and equally as human is the experience of suffering. ${ }^{29}$ Juxtaposing these two seemingly paradoxical experiences and intentionally creating meaning from the combination forms the heart of our humanity, as is evidenced by the theology of hope and psychology of meaning that emerged out of World War II. ${ }^{30}$ As Moltmann put it, "The theology of hope was born in a prisoner of war camp." ${ }^{31}$ The process of hope is not easy or comfortable, but it is essential - it is bound up in the essence of what it means to be human.

Viktor Frankl continued to do what was right even when he had very little agency as he lived through World War II concentration camps, and this ability to choose to live with a sense of meaning sustained his hope. He could not control his fate, but he could continue to serve his fellows by volunteering to care for typhus patients, for example, and by refusing to attempt escape when it meant leaving a patient for whom he represented a last shred of hope. He expressed feeling a sense of rightness within himself when he made these choices that aimed toward a broader goal than his own life, a deeper meaning. It pointed toward his participation in humanity. He came to see unavoidable suffering as an aspect of an individual's unique work in the world, and discussed the courage it took to face suffering with hope: with the willingness to still find meaning. ${ }^{32}$

Moltmann shares about his experience after the war that he and his fellow seminarians would not have accepted a "liberal, bourgeois theology," but they needed a full Christian theology that could handle the suffering and liberation of Jesus. ${ }^{33}$ Though perhaps one generally imagines suffering and hope at opposite ends of a spectrum of experiences, 
Moltmann's need for a theology of suffering brought him to a theology of hope.

\section{Relationship between suffering and hope}

I would venture to guess that most of us today who fancy ourselves ecotheologians have not experienced anything close to the physical and emotional suffering of Europe during World War II, and so we may wonder if we can yet experience hope fully. Frankl gives us a helpful metaphor. He likens suffering to a gas that is released in a jar. If there is a small amount of this gas, it will still become distributed throughout the jar, though in a smaller concentration than it might if more gas were placed in the jar. ${ }^{34}$ So it is with suffering. Though we may not have experienced the degree of suffering of those who went through concentration camps, we have experienced suffering and know its ability to impact our full selves. These authors, along with Freire and others, note that it is not the amount of suffering we endure that matters. What matters is our consciousness of it, and what we do with it. ${ }^{35}$ We all experience suffering. Those who emerged from World War II with hope had learned to transform those experiences through facing reality and making meaning. This meaning is hope's catalyst.

\section{Importance of community}

One other point needs to be brought forward regarding hope before I move into an explanation of an ecotheology of critical hope, and that is the importance of relationships and community in finding and maintaining hope. In addition to hope and suffering, our need for relationships and community is an important aspect of what it means to be human. ${ }^{36}$ Psychological studies show that involvement in communities may be essential to the act of hoping. Zimmerman found that individuals can learn hopefulness and that this happens mainly within the context of community organizations. He found that participation in these communities helped individuals develop psychological empowerment or selfefficacy outside the therapeutic setting. In addition to helping people develop skills, communities also encourage collective motivation that provides agency toward a shared goal. ${ }^{37}$ Although his study did not go so far as to interpret the reasons for an increase in psychological empowerment, my interpretation is that communal, successful goal completion 
provides a repository of stories from which individuals can draw sustaining power as they attempt a new goal. Individuals joining such a community have not experienced the previous successes, but can still draw on their agential power as they hear stories from their peers.

Philosopher Victoria McGeer talks about the concept of "peer scaffolding" as an important step in human development leading to hopeful individuals. As infants and children, we need "parental scaffolding": We need our parents or other adults to set tasks for us that are just beyond our reach so that we can learn new skills and understand ourselves as individuals who can accomplish difficult tasks. As adults, it is important to learn to be a "self-scaffolder," to be able to motivate oneself toward a goal and in so doing to build up one's self-esteem and self-efficacy, but this is not enough. ${ }^{38}$ Of vital importance is peer scaffolding, or relationships where we encourage one another to stay motivated, make meaning together through sharing our stories, and become a community that celebrates successes and urges us to try again in the face of failure. ${ }^{39}$ We need the support of others in order to continue to hope: We need an interdependent network of care. Peer scaffolding works because we recognize others as agents in their own right, with meaningful hopes and goals, and in so doing we care for those others. When we care for others, they are better able to respond in kind. We open up an expansive space where they, too, can respond to the world more expansively. ${ }^{40}$ Through acting as an agent who encourages others to hope, we learn our agential power, and this gives meaning to our own life and offers purpose and efficacy to our own actions.

\section{Christens et al.'s (2013) study on critical hope}

Building on the necessity of strong communities and peer relationships that motivate one another toward hope, the framework of critical hope helps elucidate the role of the theologian, prophet, and others in understanding how to move from critique into hope-filled action. A study by Christens et al. identified four types of civic engagement in the United States based on individuals' perceptions of their ability to effect change (self-efficacy) and their knowledge and understanding of the sources of social issues (degree of critique of social systems): critical but alienated, uncritical but hopeful, uncritical and alienated, and critical and hopeful (see Table 1). ${ }^{41}$ 
Table 1. Findings of Christens et al. (2013) rating individuals' social critique and level of hopefulness that their actions can effect change

\begin{tabular}{|c|c|c|c|}
\hline & & \multicolumn{2}{|c|}{ Self-efficacy: perception of ability to effect change } \\
\hline & & Alienated & Hopeful \\
\hline \multirow[t]{2}{*}{$\begin{array}{l}\text { Social } \\
\text { critique }\end{array}$} & Critical & $\begin{array}{l}\text { Critical but alienated ( } 48.4 \%) \text { : } \\
\text { high level of social critique } \\
\text { but feels a lack of ability to } \\
\text { influence the system. More } \\
\text { likely to be low SES }\end{array}$ & $\begin{array}{l}\text { Critical and hopeful }(7.5 \%) \text { : } \\
\text { high levels of both social } \\
\text { critique and perception of } \\
\text { ability to effect change, } \\
\text { tended to be younger }\end{array}$ \\
\hline & Uncritical & $\begin{array}{l}\text { Uncritical and alienated } \\
(20 \%) \text { : neither critical of } \\
\text { social systems or certain of } \\
\text { abilities to effect change }\end{array}$ & $\begin{array}{l}\text { Uncritical and hopeful } \\
\text { ( } 23.4 \% \text { ): uncritical of social } \\
\text { systems, but hopeful that } \\
\text { they would be able to } \\
\text { effect changes if necessary. } \\
\text { More likely to be high SES } \\
\text { and educated }\end{array}$ \\
\hline
\end{tabular}

While both "hopeful" groups had stronger community connections and both "critical" groups had better overall mental health, the combination of "critical" and "hopeful" generated the highest social capital, in addition to the benefits of mental health and community participation. Those who were critical and alienated did not have strong connections to community groups, but both Christens et al. and Zimmerman showed that as people became involved in such groups, they were able to move toward the "critical and hopeful" category. ${ }^{42}$ These types of communities are "settings that promote critical reflection on action, but do so in the context of enduring relationships, social support, shared meaning, and sense of community." 43

Developing groups that are able to be critical of current systems (where appropriate) as well as have the self-efficacy and social capital to effect change is an important aspect of a democratic society. That over half of the people in the study expressed feelings of alienation, of not having an impact on the way society works, while only $7.5 \%$ were able to critique the social order while simultaneously feeling enough empowerment to be hopeful about their ability to change the situation, shows a crisis of hope in American democracy, and American life in general. As Christens et al. conclude, it is important, therefore, to involve more individuals in the kind of community organizations that foster both social critique and hopefulness about one's level of agency. ${ }^{44}$ The church and 
other religious organizations are well situated to enact this form of community.

\section{The theologians' choice}

It is here that the would-be ecotheologian must make a choice: Presuming that he or she sees the reality of the environmental problems facing our planet today and holds a vision of a better world, will the theologian seek only to understand the situation in light of faith and beliefs, or will the theologian risk practicing hope as a true prophet, interpreting the data into transformative practice, and building community and solidarity through an ecotheology of critical hope? Are we willing to take the step that goes beyond fear of the future, beyond denouncing fossil fuel companies, beyond despairing that we have no ability to effect change, beyond feeling that our personal choices cannot make a difference, and stand against the system that currently enslaves us as both oppressor and oppressed? If we are ready to make that leap into an ecotheology that fuses the two sides of the prophetic role of critique and hope, how do we begin?

\section{The categories of Christens et al. applied to climate change and ecotheology}

To unpack the Christens et al. study in light of this discussion, I suggest that climatologists are mainly in the "critical and alienated" category (see Table 2). They are critical of the situation facing the planet, but as the years have gone by with more and more people sounding the alarm and the world continuing to go in the same direction toward ever-worsening anthropogenic climate change, they do not have a high degree of hope that they can impact the system. They fear that the world will not change and will run out of time if they ever do decide to change, so they utilize the prophetic motif of apocalyptic warning. They can imagine the world for which they hope and long, but they despair of reaching it. In some ways this is good news: They are still, in a sense, hoping. Despair shows the presence of an underlying hope, the "hope that has lost its bearings" mentioned by Freire above. ${ }^{45}$ Apathy indicates a loss of hope, but fear and despair show that one is still hoping. ${ }^{46}$ To be sure, it is a dormant hope without a sense of self-efficacy, agency, or a pathway to reach one's goal. When theologians follow this line of thinking, they end up in the same place of despair as their climatologist colleagues. Virtue ethicists 
Table 2. Christens et al. categories applied to climate change and theology

\begin{tabular}{|c|c|c|c|}
\hline & & \multicolumn{2}{|c|}{ Self-efficacy: perception of ability to effect change } \\
\hline & & Alienated & Hopeful \\
\hline \multirow[t]{2}{*}{$\begin{array}{l}\text { Social } \\
\text { critique }\end{array}$} & Critical & $\begin{array}{l}\text { Critical but alienated: virtue } \\
\text { ethics; climatologists, } \\
\text { theologians; focus on right } \\
\text { belief and personal virtue }\end{array}$ & $\begin{array}{l}\text { Critical and hopeful: } \\
\text { liberation theology; } \\
\text { prophets; focus on social } \\
\text { transformation }\end{array}$ \\
\hline & Uncritical & $\begin{array}{l}\text { Uncritical and alienated: } \\
\text { hedonism, egoism; } \\
\text { rejection of climate } \\
\text { change policies based on } \\
\text { personal right, little } \\
\text { recognition of impact on } \\
\text { others }\end{array}$ & $\begin{array}{l}\text { Uncritical and hopeful: } \\
\text { altruistic; priests/pastors, } \\
\text { religious people } \\
\text { comfortable with the status } \\
\text { quo; focus on responsibility } \\
\text { and one-size-fits-all equality }\end{array}$ \\
\hline
\end{tabular}

often fall into this category, emphasizing personal virtue but not necessarily translating this into a social critique that looks at root causes of social problems. Virtue ethics attempts to address the symptoms of poverty, climate change, and so forth, but has a difficult time catalyzing this into meaningful action in solidarity with others.

The feeling of being "uncritical and alienated" is what drives the domination system described by Freire. These individuals focus on personal rights from a Hedonistic and Egoistic perspective, with little or no awareness of how this affects others around them. They do not particularly want to change the social system, except perhaps to reduce it as far as possible so that individuals are free to make their own choices. Although these people feel alienated in terms of making changes to the system as a whole, they seem to have a fairly high degree of agency for making changes within their own lives, for getting the things that they want and need for themselves.

Unfortunately, for this reason, many of us feel forced to act in this way, too-hence the "tragedy of the commons," where everyone anxiously grabs for as many resources as possible since otherwise someone else will get them and we fear we will not have enough. ${ }^{47}$ This perspective is the fuel for an individualist rather than a collectivist perspective, and many of us participate in this system not because we want to or believe in it, but because without a strong social network to trust to collectively provide for the needs of all in the group, we see no other choice than fending for ourselves. 
The "uncritical but hopeful" group is characterized by altruistic people who really do want what is best for the whole, but are generally satisfied with the way things are. These may be pastors or priests within religious settings, individuals who want to offer comfort and support and who do not see theology or prophecy as their calling. Many people of faith fall into this category as well. They are regular church-goers, responsible members of society, and though they may have to work hard, they are making it, and they think others can work hard and make it, too. These individuals often have a vague vision of a Utopia, but passively anticipate its appearance in their lives (or after death). They believe in equal rights, that each person should be treated the same way. This is the justice as fairness approach of Rawlsian justice, without attention to historical disparity that still influences the ability for "equal opportunity" to be meted out equally. ${ }^{48}$ They believe everyone will have an equal voice in a democratic system, and therefore, they are hopeful about their own ability to impact the system. They are probably right that they could impact the system if they so chose, because they have the education and the means to do so, but they do not have major critiques of the social system because they are part of the group that is benefitting from that system. It is this group of people about whom Marx said that religion is the opiate of the people.

In the United States, many Christians fit this "uncritical and hopeful" description, and practice something more like a civil religion than anything resembling what Jesus taught. The current system provides comfort and justification for their belief that hard work is rewarded, and they see no need to reflect on the centuries of racial and other kinds of power imbalances placing them in a situation of privilege. Regarding climate change, if they believe it, they believe it will be solved by a vague idea of technical fixes and human ingenuity. "We have always solved our problems in the past, right?" the thinking goes. "Someone will solve this one, too." Others disbelieve climate change because the increasingly shrill messaging of its proponents is much less reassuring than the calm explanations of fossil fuel companies, who make their lives more comfortable and who explain away climatologists' claims with information that certainly looks like authentic science. ${ }^{49}$

The final group is "critical and hopeful." These individuals are able to realistically see and critique the world's social systems, and to remain 
hopeful that their actions will make a difference, even if that difference is simply struggling for something meaningful rather than living a life of meaningless complacency or despair. The studies by Zimmerman and Christens et al. show that these individuals are generally supported by strong social networks through their involvement in community organizations. Although they may not come from politically powerful demographic categories, critical hopers can mobilize and make a big difference, such as the famous examples of the Civil Rights Movement and Gandhi's nonviolent resistance movement for Indian independence. These individuals are motivated by being part of something greater than themselves, and through involvement in community organizations, they are able to gain skills and self-confidence, leading to self-efficacy, which provides further fuel for their hope. Critical hopers are generally thinking in a broad time scale, such as the image used by Martin Luther King, Jr.: "the arc of the moral universe is long, but it bends toward justice." 50

Within theological frameworks, liberation theology fits into this category. It strives to enact a praxis-oriented faithfulness based on critical hope. Placing themselves within a larger story, everyday actions and struggles gain deeper meaning and significance, and hope derives from experiential knowledge of an intimate God at work within struggle and suffering, as well as transcending the present moment with view to a larger goal. $^{51}$

\section{Shifting categories}

The bad news, for those of us who want to live in and encourage the idea of critical hope, is that Christens et al. showed that only $7.5 \%$ of their study population expressed the characteristics of critical hopefulness. ${ }^{52}$ The good news is that the categories are not static. Psychological studies show that individuals can learn how to practice hope and engage meaning in their lives, often through involvement in community organizations. ${ }^{53}$ Unfortunately, faith communities can operate from an "uncritical and hopeful" perspective, fostering a civil religion that sanctions the actions of the state rather than critiquing them and making governmental policies more just. And scholars in the religious academy tend to operate within the "critical but alienated" category, seeing the changes that need to occur and calling them out but not feeling the agency to change the system. Faith communities and theologians yet hold unique potential 
for the cultivation of critical hope. They are part of already-established community organizations, and their constituents generally espouse either hope or social critique.

Those in the "uncritical and hopeful" category may move toward social critique if their situation begins to become uncomfortable. They may begin to question the certainty with which they hold their low level of social critique. For those who grew up in the middle class but see their children struggling to find jobs that will pay their bills, they can see with their own eyes that hard work does not necessarily end in social rewards of a living wage. For those who have a natural gas fracking facility built near their home, the environmental impact becomes painfully obvious. These individuals can be fairly easily mobilized to work on a particular issue once the issue comes to their attention. They have some power in the sociopolitical system, so they are already somewhat hopeful (or at least optimistic). If they see the problem, they may work on it. For example, many in the middle-class American church have become aware of the problem of human sex trafficking in the United States and have mobilized to work against this problem in the last decade.

The difficulty is sustaining this group's interest for long enough to ensure that a problem is fully worked out. Once they no longer see it, it is easy to go back to comfortable passivity. Another danger is that these individuals can move to the "alienated" category if they are not able to see the effects of their actions. At this point, they can choose the "critical and alienated" category if they have become sufficiently conscious of the social problems facing the world, or they may give up and ignore social critiques, becoming apathetic and letting go of hope for change.

Those who are critical but alienated can also be moved into a critical, hopeful perspective if they begin to perceive themselves as having selfefficacy: if their actions begin to have meaning and purpose, and/or if they see some forward progress in moving toward their goal. For example, many seem to be gaining cautious hope after the Paris climate talks in December 2015, COP21. Since the presence of despair shows that a spark of hope still exists in this group, igniting hope in these individuals can occur through encouraging participation in relationships and communities of critical hope. Encouraging individuals to see themselves within the context of a broader story with a depth of meaning can give these individuals a sense of agency they do not feel when focused only on their 
personal stories of success and failure. The combination of a sense of meaning that fits into a larger story plus the synergistically agential power of involvement in community organizations can provide activate hope in those who are despairing.

The group that is neither critical nor hopeful is more difficult. Since they exhibit apathy, they no longer have a desire for hope that can easily be catalyzed. It is possible that if enough people get on board with a critical and hopeful perspective and begin making changes, those within the uncritical and alienated group may begin to take note, and may change their perspective. They may move into the "critical" category, becoming aware of social problems and why they are important. At the very least, enacting critical hope can disarm the power of the uncritical and alienated group. If their power lies in the fear that there will not be enough to go around, that there is someone who will always grab for a larger piece of the pie, the best way to combat this is not by taking one's own large piece of pie, but by sharing what one has so that others do not have to fear not having enough. As more individuals authentically care for one another, the need for acting in an uncritical and alienated way disappears, and more people can realistically choose the option of critical hope. And it is encouraging to note that this group comprises only $20 \%$ of the people studied, so if the other groups are catalyzed in the direction of critical hope, this group becomes only a small, fearful voice.

This may sound unrealistic and Utopian, and perhaps it is. But there is good evidence that those living within strong networks of communities who hold critical hope are psychologically healthier, have better overall life satisfaction, and even exhibit better physical health. ${ }^{54}$ Those with critical hope recognize that there will always be suffering; it is an unavoidable part of the human condition. But through the process of making meaning from suffering together and choosing to practice hope, strong communities form that can effect positive change in the world.

\section{Toward an ecotheology of critical hope}

The important difference between critical alienation and critical hope is an epistemic one: from orthodoxy (right belief) to orthopraxy (right action). ${ }^{55}$ In other words, the movement is from a theology that only talks to one that also acts. It is living by the spirit of the law, rather than the letter of the law: living out love relationally through our actions, 
rather than legalistically holding onto "orthodox" beliefs simply because those are the words that have been passed down to us. Utilizing orthopraxy, we see the theological task as knowing God through lived experience rather than simply understanding things about God. We learn to identify right living relationally, in immanent context, and with an epistemology that is intensely personal as well as universally connecting.

Here is where the idea of critical hope and the importance of enacting both sides of the prophetic role come into play regarding environmental concerns. If theologians simply engage in orthodox beliefs and interpret scientifically orthodox information about climate change but go about our ordinary lives, considering our job finished, whose job is it to enact the changes necessary to mitigate climate change, to engage in orthopraxy? Housed safely within the academy, how do we know about the human experiences of suffering that our lifestyle engenders? Writing at a desk, when do we experience the wonder of creation and the intense groaning of a degraded landscape?

The much-quoted ecotheology passage, Romans 8:18-25 (NRSV), is illustrative here:

I consider that the sufferings of this present time are not worth comparing with the glory about to be revealed to us. For the creation waits with eager longing for the revealing of the children of God; for the creation was subjected to futility, not of its own will but by the will of the one who subjected it, in hope that the creation itself will be set free from its bondage to decay and will obtain the freedom of the glory of the children of God. We know that the whole creation has been groaning in labor pains until now; and not only the creation, but we ourselves, who have the first fruits of the Spirit, groan inwardly while we wait for adoption, the redemption of our bodies. For in hope we were saved. Now hope that is seen is not hope. For who hopes for what is seen? But if we hope for what we do not see, we wait for it with patience.

In this passage, it is clear that the world is not as it should be: There is a critique. Things need to change. Suffering and hope are juxtaposed here, as in Moltmann and Frankl. We are suffering from a system that causes us anxiety and fear, but we also have hope because we can envision the world as it should be. The whole creation participates, groaning 
in this lament, simultaneously critiquing, suffering, and hoping. The words translated "waits with eager longing" have a meaning of continuous, active, expectant hoping. The word for "waiting," $\alpha \pi \varepsilon \kappa \delta \varepsilon \chi о \mu \alpha$, is in the middle mood, meaning it is a reflexive action in which the creation is acting and receiving the benefit of the action. When we participate in creation's groaning and longing, we receive the benefit of this action. Our act of hoping engenders hope. By participating in the process with the whole of creation, by becoming conscious of our place in this process, we can receive the benefits of this eager longing and hoping.

Theologians and other people of faith are situated in an ideal location for enacting this ecotheology of critical hope. The key is forming communities capable of critical hope, and so, even for many theologians and people of faith, forming a community or finding one that is already showing signs of critical hope is an important first step. As ecotheologian Jennifer Butler puts it, "Discomfort with isolation became my catalyst. I realized the only antidote to my growing sense of displacement was replacing alienation with rootedness." ${ }^{\text {"5 }}$ She intuitively realized that she needed the agency that comes with participating in a critically hopeful community, rooted in her faith tradition. Combining hope theory with liberation pedagogy and political theology, in this next section I will show how communities of faith can interpret the warnings of climatologists into actions of critical hope that can transform our planet in a positive direction.

\section{Praxis: combining hope theory, critical hope, and theology into reflexive action}

Bozalek et al. calls the process of enacting critical hope "goal-directed social praxis." ${ }^{57}$ Within the context of our larger hope of participating in creation in a way that allows creation to be "set free from its bondage to decay" in order that it may "obtain the freedom of the glory of the children of God" (Ro 8:21), it is important to set smaller, realistic goals that embody steps in the direction of our overall hope. Therefore, the first step for theologians who would like to interpret climatological information into action is to decide on a preliminary, feasible goal. If one does not already have a community with whom to journey in this process, developing or joining such a community could be an important first goal.

Inherent in this goal formation process is a critique: We must recognize a problem that is occurring that we may be able to address with our 
actions. In order to do this, we engage critical thinking, and we also must be willing to be personally transformed. For academics, this might look like letting go of the banking model of education and being willing to allow others to be or become experts. Part of this process may evoke a sense of personal conviction about one's role in the unjust system that has brought about this situation, leading to confession and repentance.

In order not to become stuck in the critical and alienated category, here we must practice the full action of repentance, including actively turning around and going in another direction to orient fully toward the hoped-for world. Since theologians and climatologists are often professors within an academic setting that very much abides by the culture of domination, this is another reason that academics can feel stuck and despairing. Their very livelihood and ability to continue doing the research that contributes to our understanding of climate change is contingent on upholding a system of domination, and yet that system is the same one which is causing anthropogenic climate change. True repentance may be extremely costly and takes great courage.

It can be helpful to engage our imaginations, to imagine the world as it would look in thirty years, and then to work backward from there. ${ }^{58}$ This helps us create at least one possible pathway from our present state to where we want to be. We are enacting "'lived" critical pedagogy and curiosity about what is possible." ${ }^{59}$ As McGeer puts it, "human agency is about imaginatively exploring our own powers, as much as it is about using them." 60

To find the agency to take this step, we can reflect on our personal history: Are there ways we have already been engaging in pro-environmental behavior that can encourage us to continue in that direction? Are there stories from our larger community of faith or from our sacred scriptures that provide a solid foundation from which our chosen action can flow? By engaging our personal and communal histories, we make meaning of the action we plan to perform. Therefore, even if it is difficult or uncomfortable, even if we feel afraid, the meaning with which our stories infuse the action propels us forward with courageous hope.

Thus, agency for hope comes through transcending time. Our reflection on our faith tradition's past is meaningful "only if hope in the future takes root in the present." 61 Through this action of stepping outside of time, we are able to see a broader vision of the meanings of our actions, 
living fully in the present in light of this eschatological perspective. To enter into this space, prayer, meditation, and time spent in nature are all ways that conservation psychologists are finding that individuals gain agency to do environmental work. ${ }^{62}$ Faith communities have long found power and courage in these practices, and prayer, meditation, and time in nature should not be forgotten or neglected as spiritual practices and catalysts for action.

Finally, it is important to notice what we have accomplished. After we attempt each step, we can give our communities and ourselves time to celebrate the action and make meaning of it. If it was not as successful as hoped, transforming that disappointment into a learning opportunity can yet catalyze the next step. Acknowledging the good work that has occurred and making it part of the collective identity of the group can add another story to the repertoire of meaning-filled agency that can provide support for taking the next step. Enacting this recursive process of reflection and critique leading to action within a community can provide a space where critical thinking is developed and valued, and individuals learn new skills that engender a sense of self-efficacy, enabling them to realistically attempt ever more ambitious goals within the context of a communal support network.

\section{Hope for (eco)theology?}

Theologians are faced with an epistemic choice when it comes to our interpretive role: Do we choose a theology of orthodoxy, where we are paralyzed in critical alienation by the system in which we are both privileged and oppressed? Or do we choose a prophetic theology of orthopraxy, recognizing that knowledge comes from the both/and of reflection and action, the already and the not yet, poverty and community, immanence and transcendence, self-efficacy and radical interconnectedness? ${ }^{63}$ Can we fuse futility and utopia into a meaningful, embodied hope for this day ${ }^{64}$

Making this courageous choice, we propel ourselves into a messy, uncertain world in which we may not be as comfortable as we used to be, but neither must we feel paralyzed in existential despair. Instead, our lives will be filled with purpose, relationships, community, and hope. Our actions will be multiplied as we trust one another and open up a space for others to not have to fear being crushed by a system of domination 
and oppression. Participating in the act of critical hope, we receive the benefit of that action, living out the most human of all emotions, and in the process becoming most fully ourselves within an ever-renewing context of interwoven creation.

\section{Notes}

1. This inclusio came to my attention in a series of excellent talks given by Barbara Rossing at Wake Forest School of Divinity's Food, Faith, \& Religious Leadership Institute in June 2015.

2. Bajaj, Vikas, "Climate Prophet In Hot Water," New York Times 161.55728 (2012), p. 12. Begley, Sharon, "The Evolution of an Eco-Prophet," Newsweek 154.19 (2009). pp. 34 39. Clynes, Tom, "The Prophet of Melt," Popular Science 271.2 (2007). pp. 52-106. Doran, Chris, "Environmental Curses and Blessings through the Eyes of the Biblical Prophets," Worldviews: Global Religions, Culture \& Ecology 15.3 (2011), pp. 291-304. Frese, Stephen J., "Aldo Leopold: An American Prophet," History Teacher 37.1 (2003), pp. 99 118. Hoggett, Paul, "Climate Change and the Apocalyptic Imagination," Psychoanalysis, Culture \& Society 16.3 (2011). pp. 261-75. Kool, Richard, "Limits to Growth, Environmental Science and the Nature of Modern Prophecy." Ecological Economics 85 (2013), pp. 1-5. Moo, Jonathan, "Climate Change and the Apocalyptic Imagination: Science, Faith, and Ecological Responsibility," Zygon: Journal of Religion $\&$ Science 50.4 (2015), pp. 937 48. Paterson, James, "Tim Flannery: Climate Prophet," Institute of Public Affairs Review 63.2 (2011), p. 6. Shteir, Seth, "Desert Prophets." National Parks 84.1 (2010), pp. 7. Stephens, Bret, "Climate Prophets and Profiteers," Wall Street Journal, Eastern Edition 263.39 (February 18, 2014), p. A11. Vitello, Paul, "Jane Holtz Kay, a Prophet Of Climate Change, Dies at 74," New York Times (November 21, 2012).

3. Clingerman, Forrest, "Theologians as Interpreters - Not Prophets - in a Changing Climate," Journal of the American Academy of Religion 83.2 (2015), p. 337.

4. Migliore, Daniel L., Faith Seeking Understanding: An Introduction to Christian Theology, second edition (Grand Rapids, MI: Wm. B. Eerdmans Publishing Co, 2004).

5. Clingerman, 2015, p. 340.

6. Karl Marx in Meeks, M. Douglas, Origins of the Theology of Hope (Philadelphia: Fortress Press, 1974). p. 136; and Gutiérrez, Gustavo, A Theology of Liberation: History, Politics, and Salvation, translated by Caridad Inda and John Eagleson, revised edition (Maryknoll, NY: Orbis Books. 1988), p. 123.

7. Brueggemann, Walter, The Prophetic Imagination, second edition (Minneapolis, MN: Fortress Press, 2001).

8. Lesen, Amy E., ed., Scientists, Experts, and Civic Engagement: Walking a Fine Line (New Orleans, LA: Ashgate Publishing Company, 2015).

9. Macy \& Johnstone (2012) liken this to a newspaper photograph. Viewed under a magnifying glass, each dot is visible but meaningless. Seen in aggregate, the picture emerges, which could not exist without the multitude of tiny points and their relation to one another. Macy, Joanna, and Chris Johnstone. Active Hope: How to Face the Mess We're in without Going Crazy (Novato, CA: New World Library, 2012). Brueggemann, Walter, The Prophetic Imagination. second edition (Minneapolis, MN: Fortress Press, 2001). 
10. Clingerman, 2015, p. 346.

11. One might point to the apostle Paul as a theologian, but his life did not look very much like the lives of today's theologians. He did not sit in an academy pondering theological concepts. He planted churches and wrote about his theological convictions based on his personal experiences of a Living Christ, and his topics were often deeply related to the contextual issues facing the people to whom he wrote. These were specific and experiential instructions for a particular community set in a particular place and time. As such, they often speak to us in other places and times, and there is deep universal wisdom due to the contextuality of his messages. But this form of theology looks much different from that practiced by many theologians today, intending to be universal and in so doing, having a difficult time connecting with reality in any time and place.

12. Meeks, 1974 , p. 140.

13. Freire. Paulo, Pedagogy of Hope: Reliving Pedagogy of the Oppressed, Kindle edition (London; New York: Bloomsbury Academic, 1992, 2014)._. Pedagogy of the Oppressed. Translated by Myra Bergman Ramos, 30th anniversary edition (New York. NY: Bloomsbury. 2000).

14. Bozalek, Vivienne, Brenda Leibowitz, Ronelle Carolissen, and Megan Boler, Discerning Critical Hope in Educational Practices (New York, NY: Routledge, 2014).

15. Ainley, Patrick, and Joyce E. Canaan, "Critical Hope in English Higher Education Today, Constraints and Possibilities in Two New Universities," Teaching in Higher Education 10(4) (October 1, 2005). pp. 435 46. Canaan, Joyce, "Developing a Pedagogy of Critical Hope," LATISS: Learning and Teaching in the Social Sciences 2.3 (2005). pp. 159-74. Danvers, Emily, "Discerning Critical Hope in Educational Practices," Higher Education Research \& Development 33.6 (2014). pp. 123941.

16. Christens, Brian D.. Jessica J. Collura, and Faizan Tahir, "Critical Hopefulness: A PersonCentered Analysis of the Intersection of Cognitive and Emotional Empowerment," American Journal of Community Psychology 52.1-2 (2013), pp. 170-84.

17. Cahill, Caitlin, David Alberto Quijada Cerecer, and Matt Bradley, "'Dreaming of ... ': Reflections on Participatory Action Research as a Feminist Praxis of Critical Hope," Affilia 25.4 (2010). pp. 406 -16. Miller, Peter M., Tanya Brown. and Rodney Hopson, "Centering Love. Hope, and Trust in the Community: Transformative Urban Leadership Informed by Paulo Freire," Urban Education 46.5 (2011). pp. 1078-99.

18. With the exception of one recent study in religious education which does a good job of outlining the field of globalized religious education but does not really get to anything about critical hope (Kim, 2015), and one dissertation about a pedagogy of critical hope in a composition classroom that attempts to elucidate the connections between Freire's liberation pedagogy and liberation theology (Kuhne, 1998). To be sure, many in the religious academy have written about justice and the environment, or the environment and hope. But valid critiques inveigh that current suggestions from these fields display unrealistic governmental policy changes and that such policies cannot be adequately just for all people and for all time. Concerns leveled at ecotheologies of hope are their Utopian nature and their simplistic optimism. I share these concerns and hope to address them here. Kim, Hyun-Sook, "Seeking Critical Hope in a Global Age: Religious Education in a Global Perspective," Religious Education 110.3 (2015). pp. 311-28. Kuhne. Michael Collins, "A Community Pedagogy of Critical Hope: 
Paulo Freire, Liberation Pedagogy and Liberation Theology," Ph.D. dissertation. University of Minnesota, 1998.

19. Freire, 1992, 2014; Freire, 1970, 2000.

20. Freire, 1970, 2000: p. 32.

21. Kuhne, 1998: p. 95, 96.

22. Freire, 1992, 2014: loc. 84-85.

23. Sutton, Paul, "A Paradoxical Academic Identity: Fate, Utopia and Critical Hope," Teaching in Higher Education 20.1 (2015), p. 43.

24. Meeks, 1974.

25. Martin, Adrienne M., How We Hope: A Moral Psychology (Princeton: Princeton University Press, 2013): Snyder, C.R., Handbook of Hope: Theory, Measures, and Applications, EBook Academic Collection (San Diego, CA: Academic Press, 2000).

26. Snyder, C.R., Handbook of Hope: Theory, Measures, and Applications, EBook Academic Collection (San Diego, CA: Academic Press, 2000).

27. Ibid., 2000.

28. Moltmann. Jürgen, Theology of Hope: On the Ground and the Implications of a Christian Eschatology, translated by James W. Leitch, fifth edition (New York, NY: SCM Press Ltd., 1965). Freire, $1970,2000$.

29. McGeer, Victoria, "The Art of Good Hope," The Annals of the American Academy of Political and Social Science 592.1 (2004), pp. 100 27. Meeks, 1974.

30. Moltmann, 1965. Frankl, Viktor E., Man's Search for Meaning, translated by Simon Vance (OverDrive, Inc. and Blackstone Audiobooks, 1995). If there were more time and space, I would also draw in the postmodern philosophy of Emanuel Levinas: Levinas, Emmanuel, Entre Nous: Thinking of the Other. European Perspectives: A Series in Social Thought and Cultural Criticism (New York, NY: Columbia University Press, 2000).

31. Moltmann, Jürgen, "Forward," in Origins of the Theology of Hope (Philadelphia, PA: Fortress Press, 1974), p. xi.

32. Frankl, 1995.

33. Moltmann, "Forward," 1974, p. xi.

34. Frankl, 1995.

35. Frankl, 1995; Freire, 1970, 2000: McGeer, 2004; Meeks, 1974; Moltmann, 1965.

36. McGeer, 2004.

37. Zimmerman, Marc A., "Toward a Theory of Learned Hopefulness: A Structural Model Analysis of Participation and Empowerment," Journal of Research in Personality 24.1 (1990), pp. 71-86.

38. McGeer, 2004, p. 108.

39. Ibid., p. 123.

40. Ibid.

41. Christens, Brian D., Jessica J. Collura, and Faizan Tahir, "Critical Hopefulness: A PersonCentered Analysis of the Intersection of Cognitive and Emotional Empowerment," American Journal of Community Psychology 52.1-2 (2013), pp. $170-84$.

42. Christens, et al., 2013; Zimmerman, 1990.

43. Christens, et al., 2013, p. 181.

44. Christens, et al., 2013. 
45. Freire, 1992, 2014: loc. 84-85.

46. Gravlee, G. Scott, "Aristotle on Hope," Journal of the History of Philosophy 38.4 (2000).

pp. 461-477.

47. Hardin, Garrett, "The Tragedy of the Commons," Science, New Series, 162.3859 (1968),

pp. 124348

48. Kim, 2015. Ahn, Ilsup. "From Colonizing Contract to Decolonizing Covenant: The Case for Ecological Justice in Maquiladoras and a New Covenantal Approach to Christian Environmental Ethics," Cross Currents 65.1 (2015), pp. 30-56.

49. E.g., The Heartland Institute, www.heartland.org.

50. King, Jr., Martin Luther, "Out of the Long Night," The Church of the Brethren Gospel Messenger (1958), pp. 3-4, 14-15. King puts the phrase in quotes, but does not cite the source.

51. Gutiérrez, 1988.

52. Christens, et al., 2013.

53. Snyder, 2000, Bartholomew, Theodore T., Michael J. Scheel, and Brian P. Cole, "Development and Validation of the Hope for Change through Counseling Scale," The Counseling Psychologist 43.5 (2015). pp. 671-702. Cheavens, Jennifer S., "From Here to Where You Want to Be: Building the Bridges with Hope Therapy in a Case of Major Depression," in Happiness, Healing, Enhancement: Your Casebook Collection for Applying Positive Psychology in Therapy, edited by George W. Burns (Hoboken, NJ: John Wiley \& Sons Inc, 2010), pp. 51-63. Cheavens, Jennifer S., David B. Feldman. Amber Gum, Scott T. Michael, and C. R. Snyder, "Hope Therapy in a Community Sample: A Pilot Investigation," Social Indicators Research, Subjective Well-Being in Mental Health and Human Development Research Worldwide, 77.1 (2006), pp. 61-78. Hodkinson, Marylyn, "Observation of Some Key Resources of the Noös in Online Logotherapy," International Forum for Logotherapy 38.1 (2015), pp. 30-33. Holland, Dennis W., "A Call for Using Logotherapeutic Principles for Healing Historical Trauma with Native Americans," International Forum for Logotherapy 38.1 (2015). pp. 14-19. Lopez, Shane J., R. Keith Floyd, John C. Ulven, and C. R. Snyder, "Hope Therapy: Helping Clients Build a House of Hope," in Handbook of Hope: Theory, Measures, and Applications, edited by C. R. Snyder (San Diego. CA. US: Academic Press, 2000). pp. 123 50. Rogina, Julius M., "Noogenic Activation in the Clinical Practice of Logo Therapy and Existential Analysis (LTEA) to Facilitate Meaningful Change," International Forum for Logotherapy 38.1 (2015). pp. 1-7. Snyder, C. R., "Hope and Depression: A Light in the Darkness," Journal of Social \& Clinical Psychology 23.3 (2004). pp. 347-51. — . "Hope Theory: Rainbows in the Mind," Psychological Inquiry 13.4 (2002). pp. 249-75. — . "Teaching: The Lessons of Hope," Journal of Social \& Clinical Psychology 24.1 (2005). pp. 72-84. Weis, Robert. "You Want Me to Fix It? Using Evidence-Based Interventions to Instill Hope in Parents and Children," in Happiness, Healing, Enhancement: Your Casebook Collection for Applying Positive Psychology in Therapy, edited by George W. Burns and George W. Burns (Hoboken, NJ, US: John Wiley \& Sons Inc, 2010), pp. 6475.

54. Clayton, Susan D., and Gene Myers, Conservation Psychology: Understanding and Promoting Human Care for Nature (Chichester, UK \& Hoboken, NJ: Wiley-Blackwell, 2015).

55. Woodley, Randy, Shalom and the Community of Creation: An Indigenous Vision, Prophetic Christianity Series (Grand Rapids, MI: William B. Eerdman's Publishing Company, 2012). 
56. Brunner, Daniel L.. Jennifer L. Butler, and A. J. Swoboda, 2014, Introducing Evangelical Ecotheology: Foundations in Scripture, Theology, History, and Praxis (Grand Rapids, MI: Baker Academic).

57. Bozalek, Vivienne, Brenda Leibowitz, Ronelle Carolissen, and Megan Boler, Discerning Critical Hope in Educational Practices (New York, NY: Routledge, 2014), p. 14.

58. A helpful format for this is Morison's "Imaging a Fossil-free Future: Visioning Workshops for a Brave and a New World," based on Elise Boulding's nuclear-free workshops. See also Macy \& Johnstone, 2012, 163-184. Morison, Mary Lee, "Imaging a Fossil Free Future: Visioning Workshops For a Brave and a New World," Earth \& Peace Education International: Values for a Sustainable Earth \& a Global Peace. July 2013. http://www.globalepe.org/article_print.php?aid $=43$.

59. Bozalek, 2014, p. 2.

60. McGeer, 2004.

61. Gutiérrez, Gustavo. A Theology of Liberation: History, Politics, and Salvation, translated by Caridad Inda and John Eagleson, revised edition (Maryknoll, NY: Orbis Books, 1988), p. 125.

62. Clayton and Myers, 2015.

63. Woodley, 2012.

64. Kamminga (2008) criticizes prophetic discourse because it focuses too much on either a sense of futility or a sense of Utopianism. but I think that if we combine both of these with realistic hope and working toward a sense of meaning rather than a specific Utopian future, we fuse the two sides of the prophetic trope into a powerful agential force. Kamminga, Menno R., "The Ethics of Climate Politics: Four Modes of Moral Discourse," Environmental Politics 17.4 (August 2008), pp. 67392. 